\title{
No que acreditar: pós-verdade e fake news como estratagemas políticos ${ }^{1}$
}

Theo Villaça

Pontifícia Universidade Católica do Rio de Janeiro - PUC-Rio

Departamento de Comunicação Social - Bacharelado em Jornalismo

\section{RESUMO}

Este é um trabalho do campo da Comunicação que tem como objetivo analisar os fenômenos da pós-verdade e das fake news a partir de autores do século XX. O crescente uso dessas expressões, a partir do ano de 2016, revela um aumento do interesse no tema. Para a análise, procurou-se a bibliografia corrente sobre pós-verdade e fake news e suas consequências políticas diretas e indiretas. Verificou-se, entretanto, que tais fenômenos eram estudados anteriormente às presentes nomenclaturas, apesar das especificidades atuais. Primeiramente, utilizou-se uma bibliografia que concerne o emissor, qual seja, sobre o estudo da retórica. Posteriormente, concernente ao receptor, com foco na emergência da sociedade de massa. Analisando o emissor e o receptor, buscou-se construir um todo coerente. Concluise que a pós-verdade e as fake news são fenômenos antigos, mas potencializados pela situação contemporânea e usados para fins políticos.

\section{PALAVRAS-CHAVE}

Retórica; Aristóteles; Sociedade de Massa; Indústria Cultural.

\section{Introdução}

A partir do ano de 2016, duas expressões emergiram na tentativa de explicar novos fenômenos políticos: fake news e post-truth, esta última traduzida no Brasil para "pósverdade". O ano foi marcado no mundo anglo-saxão por duas votações de extrema importância para o futuro das duas grandes potências anglófonas, os Estados Unidos e o Reino Unido.

\footnotetext{
1 Artigo derivado de monografia de graduação em Jornalismo, orientada pelo professor Gustavo Chataignier e apresentada em julho de 2019.
} 
A primeira, a eleição presidencial norte-americana, entre os candidatos Hillary Clinton e Donald Trump. A segunda, o referendo sobre a saída ou não do Reino Unido da União Europeia, da qual são membros desde 1973.

Ambas as eleições foram marcadas pela disseminação de fatos não comprovados ou mesmo de simples mentiras de ambos os lados. Essas são as chamadas fake news, inicialmente proferidas pelo candidato Trump contra a mídia americana, mas logo depois sendo parte da crítica ao próprio republicano, que estaria disseminando notícias falaciosas.

Donald Trump e o Brexit (nomenclatura utilizada para a saída do Reino Unido da UE) saíram vitoriosos. A conquista de ambos fez com que as acusações aumentassem, partindo da premissa que as fake news foram determinantes para o resultado dos pleitos.

Já a pós-verdade é um adjetivo, então o adequado é falar em era da pós-verdade, política da pós-verdade ou retórica da pós-verdade. Esse fenômeno diz respeito ao momento em que os indivíduos privilegiam suas crenças acima de acontecimentos atuais ou históricos.

Uma novidade na era da pós-verdade é uma diferença na arte da retórica, seja para a clássica, seja para a moderna, como apontou McComiskey. Segundo o autor, agora mais do que antes, o emocional e a subjetividade das pessoas são explorados para fins políticos, como aconteceu principalmente na eleição nos Estados Unidos (McCOMISKEY, 2017). McComiskey, então, analisa discursos do presidente eleito Donald Trump, para demonstrar sua especificidade.

Sua percepção é a de que o discurso dos políticos da pós-verdade são desprovidos de apelo racional, que Aristóteles denominou logos, em sua retórica (ARISTÓTELES, 2011). Ao invés do logos, há a predominância do apelo emocional, característica fundamental da era da pósverdade. Essa novidade em termos de retórica será comentada no segundo capítulo, com o contraste entre a retórica dos sofistas, opositores de Platão e Aristóteles.

A retórica da pós-verdade se intensifica, pois encontra receptores adequados. Dois fatores promoveram essa situação. O primeiro é a ascensão da sociedade de massa, e o segundo, seus meios de comunicação de grande alcance. 
A sociedade de massa acarretou em um nivelamento por baixo dos receptores, os quais se tornam menos críticos ao que Ihes é exposto ou emitido. Segundo o filósofo espanhol Ortega y Gasset, a modernidade viu o indivíduo médio, sem qualidades especiais, tomar conta do espaço público, antes composto por indivíduos de muitas capacidades. Tal homem-massa está satisfeito com o medíocre e busca apenas ser igual a todos, ou seja, ser padronizado. Com o homem-massa em funções privilegiadas de emissor e receptor, há mais suscetibilidade para notícias falaciosas se disseminarem.

Ademais, os meios de comunicação de massa permeiam toda a vida do indivíduo, inclusive no seu tempo livre. Bombardeado por notícias, por meio das mídias sociais, há pouco tempo para um distanciamento crítico, o que agrava a situação. Essa é uma das características da indústria cultural, tal qual exposta por Theodor Adorno e Max Horkheimer.

Outra característica que revela as fake news como mais um produto da indústria cultural é a padronização de seus conteúdos, mas com um mascaramento de novidade. Nos canais de políticos e em suas propagandas (as quais se incluem a divulgação de fake news), é mostrado um candidato que é diferente do resto e, por isso, resolveria os problemas atuais. Apesar dessa prática não ser nova na política, as mídias sociais a potencializam.

\section{Retórica na era da pós-verdade}

As definições de pós-verdade apontam para a receptividade dos indivíduos que consomem, dentre outros conteúdos, notícias. Mas, se há receptividade, há também um emissor. Para essa comunicação acontecer, é necessário, portanto, a arte da retórica por parte dos emissores, que neste caso, são políticos e suas equipes ou outros grupos com interesse e poder material suficiente para divulgação em massa.

O autor Bruce McComiskey analisa a retórica nesse novo contexto da pós-verdade em seu livro Post-Truth Rhetoric and Composition, explicando como que se dá a comunicação de fenômenos como as fake news a partir dos emissores ao invés dos receptores.

$\mathrm{Na}$ era da pós-verdade não há um vínculo com a realidade. McComiskey afirma que os retóricos devem conhecer os fatos da realidade para então mentir ou dizer a verdade. 
Segundo ele, mesmo os sofistas da antiga Grécia, notórios opositores da verdade metafísica, respeitavam um "contínuum espistemológico", que seria justamente o vínculo da mentira com os fatos sobre os quais mentiram (MCCOMISKEY, 2017). Para os sofistas havia um cuidado com acontecimentos contemporâneos a eles. Na pós-verdade, então, as fake news não tem necessariamente uma relação com os acontecimentos.

A prática sofista ganhou notoriedade na Grécia do século V a.C, com indivíduos que ensinavam a discursar. Havia, contudo, uma elaboração teórica ontológica por trás da sofística. Dentre os sofistas antigos, destacam-se dois, Protágoras e Górgias. O primeiro é o autor da paradigmática frase: "O ser humano é a medida de todas as coisas, das que são enquanto são, e das que não são enquanto não são", simplesmente colocada: o homem é a medida de todas as coisas, exposta em Sextus Empiricus (SEXTO EMPIRICO, 2005, p.14), mas também citada no Teeteto de Platão (160d).

A verdade objetiva, portanto, é posta em questão na sofística, e a centralidade recai sobre o ser humano. Para seus críticos gregos, especialmente Platão e Aristóteles, os sofistas falam "ao invés de pensar" e são pseudo-filósofos (CASSIN, 2005).

Gorgias apresentou sua teoria por meio de uma argumentação lógica, por mais que estivesse criticando alguns pressupostos lógicos. O texto de Sexto Empírico que parafraseia o sofista se chama justamente "Contra os Lógicos".

A exposição da teoria ontológica dos sofistas revela sua distinção da prática contemporânea na era da pós-verdade. Há um arcabouço intelectual que simplesmente inexiste nos discursos políticos do século XXI. Não obstante, o exemplo dos sofistas pode ser instrumentalizado para fins políticos, mesmo porque a arte da retórica é extremamente útil em regimes democráticos, nos quais deve haver persuasão.

E, segundo o próprio Gorgias, em Platão, a retórica é a arte da persuasão. No diálogo platônico "Gorgias", o sofista diferencia crença de conhecimento e revela que a retórica consiste em convencer crenças. É essa uma das primeiras teses de Gorgias, logo que indagado por Sócrates. Contudo, o auto-intitulado professor da arte da retórica diz haver conhecimento e, 
que este, deve ser verdadeiro, opondo-se a crença, que pode ser falsa ou verdadeira (PLATÃO, 1997).

Quando McComiskey chama a atenção para a perda do "continuum epistemológico" na pósverdade, atesta justamente para essa posição de Gorgias. Qual seja, de que existe conhecimento e de que ele pode ser transmitido. Há, portanto, uma diferença significativa entre os dois tipos de retóricas identificados por McComiskey. A antiga, que admite a existência de conhecimento e busca a persuasão de crenças; e a da pós-verdade, para a qual apenas a crença importa. Na segunda, nem a possibilidade de mudança de crença existe, já que os políticos da pós-verdade buscam justamente corresponder a elas.

Notório opositor dos sofistas, Aristóteles continua sendo uma das referências ao estudo de retórica, que a define como a contraparte da dialética. No capítulo 2 do livro A de sua "Retórica", são definidos três métodos pelos quais pode haver a persuasão: "O primeiro depende do caráter do orador; o segundo, de levar o auditório a uma certa disposição de espírito; e o terceiro, do próprio discurso no que diz respeito ao que demonstra ou parece demonstrar" (ARISTÓTELES, 2011, 1356a2-5).

O primeiro método diz respeito a credibilidade do orador. Parte da honestidade e do escrúpulo que o emissor tem, que, segundo Aristóteles, provoca a confiança dos ouvintes. O segundo tem como foco a audiência e seus sentimentos. Nesse caso, o orador apela para as emoções do ouvinte. Em terceiro lugar, há o método que trata do próprio discurso e sua veracidade ou verossimilhança.

Esses três métodos são identificados por Bruce McComiskey como ĩ $\theta o \varsigma$ (ethos), náӨos (pathos) e $\lambda o ́ y o \zeta(\log o s)$, respectivamente. O autor chama a atenção para o fato de que a retórica clássica e moderna tem como elemento fundamental o logos, deixando ethos e pathos como suplementos. Na era da pós-verdade, entretanto, ethos e pathos são privilegiados em detrimento do logos. Vale lembrar a definição de pós-verdade do dicionário Oxford que revela o apego do público às emoções, negligenciando a razão (McCOMISKEY, 2017). Ao contrário, os sofistas lançavam mão do logos em suas estratégias de persuasão ao público.

McComiskey analisa o ethos característico da pós-verdade, e, para isso, o exemplo é Donald Trump, a origem do debate. Segundo o autor, Trump parece estar sempre atuando, como um 
personagem. Seu ethos, portanto, transforma-se em performance. A credibilidade, aspecto do ethos, não precisa ser real, o importante é a aparência (McCOMISKEY, 2017).

A performance de Trump mostra um ethos intransigente, que faz afirmações sempre normativas como "Oh, nós venceremos". Anteriormente, políticos do establishment ${ }^{2}$ tinham como método a promessa, portanto, buscavam se mostrar dignos de confiança para a população.

No Brasil, o presidente Jair Bolsonaro, eleito em 2018, segue a mesma linha antiestablishment. Bolsonaro era o candidato que em seus discursos se opunha aos restos dos políticos, mascarando a falta de logos. A campanha do presidente eleito utilizou de um populismo, no qual seus eleitores o identificaram como alguém que "fala o que pensa" e estaria cansado da corrupção dos demais políticos. Nesse discurso, há ethos (pois ele seria honesto - de acordo com seus eleitores), e há um pathos (as pessoas também estariam cansadas da corrupção). O discurso, porém, era apenas propaganda política.

Ao mesmo tempo que a credibilidade dos políticos da pós-verdade devem aumentar, a de outros meios deve necessariamente diminuir, visto que suas versões entram em conflito (McCOMISKEY, 2017). Assim, Trump e Bolsonaro não cessam de atacar continuamente o ethos de instituições como a mídia. Para Bruce McComiskey, sempre que indagam o ethos de Trump a partir do logos, ele prontamente vira o jogo e ataca o ethos das acusações a partir do logos, isto é, de que as acusações contra ele não tem embasamento (McCOMISKEY, 2017).

O privilégio do pathos a despeito do logos é o cerne da pós-verdade, que diz respeito ao emocional da audiência. McComiskey afirma que Donald Trump usou da raiva que parte do seu público já tinha para fazê-los acreditar nas falas do presidente. O retórico que detém o controle das emoções dos ouvintes terá maior sucesso em convencê-los. Assim, Trump explorou a raiva já latente dos seus eleitores, que passaram a aceitar suas fake news como fatos, porque iam de acordo com o que estavam sentindo (McCOMISKEY, 2017). O ouvinte que já não concordava com a CNN ou outros veículos de mídia porque não apresentavam as versões nas quais ele acreditava. Quando um candidato se opôs à mídia tradicional e começou a atacá-la, o ouvinte se sentiu contemplado.

${ }^{2}$ Establishment, do inglês, diz respeito geralmente a políticos que fizeram carreira política e estão inseridos nesse âmbito. Muitas vezes devido a tradição familiar, como Aécio Neves e Rodrigo Maia. 
Apesar da uso do logos em estratégias retóricas, a arte da retórica não é como a lógica. De acordo com o autor Edward P. J. Corbett, Aristóteles salienta essa diferença (CORBETT, 1966).

Antes de tudo, os assuntos humanos são falíveis por natureza, e é sobre eles que a retórica é usada na maioria dos casos. A lógica, por outro lado, não busca persuadir, busca universais.

A existência do logos na retórica não significa que há os mesmos usos de operações lógicas, como por exemplo o silogismo. O silogismo parte de duas premissas comprovadas ou demonstráveis para se chegar a uma conclusão.

Em Aristóteles, a retórica usa do entimema para as argumentações. Corbett define o entimema como um silogismo abreviado, na medida em que uma de suas premissas é omitida. O exemplo utilizado é: "João vai reprovar pois não estudou", que não revela uma certeza (CORBETT, 1966, p. 63). A premissa omitida, nesse caso, é a de que todos os que não estudam, reprovam. Aí se configura a principal diferença da lógica para a retórica. Não é certo que João reprove, é apenas provável.

Segundo Corbett, o entimema não é uma conclusão necessária. Ele é uma estratégia de se chegar a uma conclusão possível (CORBETT, 1966). Logo, o uso da retórica será sempre falho, independentemente do uso do logos, ou seja, do apelo ao racional. Mas, ao mesmo tempo, o cotidiano e a urgência de questões públicas justificam o uso de entimemas. As questões humanas, na maioria das vezes, não apresentam verdades científicas, comprováveis por silogismos ou outra operação lógica.

Na Retórica, Aristóteles afirma que o conhecimento da verdade requer instrução, não só por parte do orador, como por parte dos ouvintes que o receberão. Daí resulta-se a necessidade da retórica, e seus três métodos para a persuasão. O público nem sempre seguirá de acordo com a predominância do logos, que corresponde ao conteúdo proferido pelo orador.

A negligência do logos, em prol do pathos e do ethos, sinaliza que houve uma queda no nível de instrução do público. Seguindo os argumentos aristotélicos, o convencimento focado, por exemplo, no apelo às emoções, era para ser utilizado como um complemento apenas. 
Bruce McComiskey salienta que esse processo se deu no novo tipo de retórica, ou seja, se deu no novo tipo de emissor, o emissor da era da pós-verdade. Mas se houvesse um discernimento, por parte do público - ou instrução, nas palavras de Aristóteles - um foco no ethos e no pathos em detrimento do logos não só não seria necessário, como seria ineficaz.

\section{As fake news na sociedade de massa}

\subsection{A mediocridade da massa}

A retórica da pós-verdade por si só não teria efeito se não encontrasse um público que a recebesse. Mesmo com a ausência de vínculo a fatos históricos, essa estratégia tem grande receptividade no público. Como anteriormente demonstrado, as fake news não são fenômeno novo na história, mas tiveram maior divulgação a partir do século XX por dois motivos: a ascensão da sociedade de massas e o aumento das capacidades técnicas de comunicação, ambas características da modernidade. A ascensão da sociedade de massas na medida em que o número de indivíduos consumidores aumentou exponencialmente; o desenvolvimento das capacidades técnicas dos meios de comunicação que permitem maior acesso das massas aos produtos.

Inúmeros autores no século $X X$ mostraram preocupação com esse novo momento da sociedade ocidental, qual seja, a sociedade de massa. O filósofo espanhol José Ortega y Gasset demonstrou sua preocupação em seu livro intitulado "A Rebelião das Massas", no qual relata a ascensão de um tipo específico de homem ao "pleno poder social" (ORTEGA Y GASSET, 2010, p.10).

O livro de Ortega y Gasset começa com a seguinte constatação: "Há um acontecimento, que para o bem ou para o mal, é mais importante para a vida pública europeia atualmente. Esse acontecimento é o advento das massas ao pleno poder social" (Ibidem, p.10). A definição do pensador de massa é colocada em contraposição ao conceito de minoria. A massa é caracterizada pelo "conjunto de pessoas não especialmente qualificadas", ou seja, um homem comum. Porém, mas do que isso, são indivíduos que se sentem satisfeitos em serem iguais aos demais (ORTEGA Y GASSET, 2010, p.14). 
O conceito de minorias, para Ortega y Gasset, não se relaciona com o atual, que diz respeito a grupos de pessoas marginalizados e que possuem menos voz política e social. Para o autor espanhol, minorias são aqueles indivíduos que têm qualidades especiais, que se destacam em meio a multidão (ORTEGA Y GASSET, 2010).

A questão do advento das massas, então, se torna um problema na medida em que esse tipo de homem medíocre ocupa espaços de decisão política e social. Uma possível consequência desse acontecimento é um nivelamento por baixo de políticas públicas. Segundo Ortega y Gasset, "homens-massa" e minorias sempre existiram. Contudo, os indivíduos que hoje compõem as massas não eram massas até o século XX, e não detinham papel principal, como de liderança política.

É necessário ressaltar que ambos os conceitos não correspondem à classe social e poderio econômico. Podem haver indivíduos excepcionais nas classes mais baixas, como indivíduos padronizados em classes altas.

As retóricas de políticos na era da pós-verdade evidenciam a ascensão do "homem-massa". Primeiramente, o surgimento de canais de mídia que tinham como objetivo reiterar o que indivíduos já acreditavam (Limbaugh e Fox News), criando um público padronizado. A massa se reconheceu nesses emissores.

Em um segundo momento, os homens-massa se reconheceram em políticos antiestablishment. Quando há um questionamento acerca das instituições públicas, e as pessoas deixaram de se identificar nelas, surgem canais diretos diretos de comunicação. Assim foi na eleição americana que elegeu Trump e assim foi na eleição de Jair Bolsonaro em 2018. E, mesmo depois de eleitos, têm suas contas de Twitter como principal meio de comunicação com a população.

Mas os próprios políticos são, também, homens-massa. Uma distinção que Ortega y Gasset faz das minorias com a massa é de que a primeira detinha um senso de responsabilidade quando em cargos públicos. A modernidade teve como consequência, devido a grande geração de riqueza, o surgimento de uma camada de indivíduos que gozam de plenas liberdades, sem as dificuldades das gerações anteriores. É o que o filósofo espanhol chama de "señorito satisfecho", um indivíduo mimado (ORTEGA Y GASSET, 2010). 
A falta de responsabilidade do homem-massa é vista, primeiramente nos receptores, que não estão no espaço público. As fake news são muito divulgadas por meio de compartilhamentos acríticos, sem uma preocupação com a veracidade de informações. Nos emissores, a irresponsabilidade é ainda mais evidente. As falas de um presidente como Donald Trump, de um país com enorme influência global, tem consequências para um grande número de pessoas.

Tal evento, Ortega y Gasset denominou "hiperdemocracia". A hiperdemocracia é o governo do homem-massa, mas de maneira mais direta, como por exemplo com o uso de canais próprios de comunicação. A hiperdemocracia é um governo da massa que impõe suas preferências ao restante da população, incluindo sobre as minorias. Suas preferências, como já comentadas anteriormente, são principalmente relativas à padronização, que passa a ser imposta de cima para baixo. O governo da massa é medíocre pois seus membros não aspiram outra coisa senão ser igual a todos (ORTEGA Y GASSET, 2010).

Essa característica, avaliada por Ortega y Gasset, é um entrave a qualquer regime, apesar de por esses meios ser um problema específico da democracia. Sem as minorias, não há inovação e não há mudança, há apenas o mesmo se repetindo.

\section{As fake news como produto cultural}

A teoria de Ortega y Gasset revela uma preocupação da ascensão da mediocridade do homem-massa dentro de âmbitos públicos. Escrevendo na mesma época, os alemães Theodor Adorno e Max Horkheimer também e se voltaram para a questão da sociedade de massa. Os filósofos da Teoria Crítica partiram, entretanto de uma perspectiva distinta. O foco deles é a emissão dos mass media (meios de comunicação de massa) cada vez mais padronizado, imposta por conglomerados da fase tardia do capitalismo, que submetem todos os âmbitos da sociedade (cultura, lazer, entretenimento) ao poder simbólico exercido.

Se, para o filósofo espanhol, o homem-massa quer ser padronizado, para os frankfurtianos essa padronização é consequência da delimitação de escolhas na sociedade de massa 
moderna. Adorno e Horkheimer traçam como uma especificidade da modernidade a Indústria Cultural. A Indústria Cultural, nas palavras de Rodrigo Duarte:

Evoca a ideia, intencionalmente polêmica, de que a cultura deixou de ser uma decorrência espontânea da condição humana, na qual se expressam tradicionalmente, em termos estéticos, seu anseios e projeções mais recônditos, para se tornar mais um campo de exploração econômica, administrado de cima para baixo e voltado apenas para os objetivos supramencionados de produzir lucros e de garantir adesão ao sistema capitalista por parte do público. (DUARTE, 2007, p. 9)

Isto significa que todos os âmbito da cultura estão submetidos ao âmbito econômico. A arte se torna apenas um produto, divulgado pelos meios de comunicação de massa. Assim também é com demais segmentos explorados pelos media, do entretenimento a informação. A Indústria Cultural é a primazia do dinheiro em relação à demais âmbitos da humanidade.

A indústria cultural foi determinante para um processo de "esclarecimento unilateral", no qual o pensamento crítico dos indivíduos deixa de existir (DUARTE, 2007), ou seja, há uma imposição de produtos de cima para baixo, dos detentores dos meios para os receptores.

No livro Dialética do Esclarecimento, os autores alemães chamam a atenção para a perda de receptividade crítica dos indivíduos aos produtos da indústria. Isso se deve porque a indústria faz ela mesma a categorização que, outrora, cabia ao indivíduo mesmo fazer. Já que este trabalho de categorizar é feito a priori, os consumidores se tornam passivos perante à recepção. Dentro da ultrarracionalidade da sociedade de massas não há espaço para a crítica (ADORNO e HORKHEIMER, 2006).

A categorização feita previamente pela indústria é também falsa, já que separa produtos que iguais. A separação entre diferentes gêneros do cinema, para Adorno e Horkheimer, esconde que na verdade são um mesmo produto. Com o aumento da propaganda política, os próprios políticos e partidos se tornam um produto, na medida em que tem que se vender a um público que deve aceitá-los ou rejeitá-los.

Durante uma eleição, também é possível notar um mascaramento da verdadeira similaridade entre opções aparentemente distintas. O papel da Indústria Cultural que distingue produtos idênticos também se revela quando dois candidatos se separam na publicidade dos respectivos partidos, mas a diferença na prática política não existe. Assim, muitas vezes o 
que é exposto como direita, esquerda, ou mesmo anti-establishment (candidato sem carreira política), na verdade não contém ideias políticas.

As experiências que o indivíduo tem com produtos do meio de comunicação sejam estéticos, ou sejam de caráter noticiário, são mediados pelos próprios meios que, por sua vez, são ligados a grandes estruturas de poder. No caso específico das notícias, os indivíduos estão sujeitos ao recorte dos próprios meios de comunicação detentores da capacidade técnica. Isso fomentou, juntamente com o descrédito na mídia tradicional, uma tentativa de canal de comunicação direta entre políticos e população por meio das redes sociais, portanto, sem a mediação de noticiários. Não há, entretanto, essa comunicação não mediada. As equipes partidárias apenas substituem os meios tradicionais pelos deles próprios. Dessa forma a situação se agrava, já que deixa de haver a possibilidade de um embate entre poderes antagonistas, há apenas a versão do próprio político e partido.

A situação na qual Theodor Adorno escreveu é semelhante a do século XXI. Políticos e suas equipes estão a todo o momento postando em redes sociais, que são os atuais media de comunicação de massas, que em meados do século XX eram o rádio e o cinema. Nos Estados Unidos, o ex-presidente Barack Obama soube usar o Facebook para sua eleição e popularidade durante o governo, e Donald Trump tem o Twitter como principal canal de comunicação com a população.

Ademais, a crítica necessita de um distanciamento do indivíduo perante ao que ele consome. Segundo os frankfurtianos Adorno e Horkheimer, não há tempo para o distanciamento. Tanto no trabalho como no descanso, o espectador é bombardeado pelos produtos da Indústria Cultural, com o auxílio da reprodutibilidade técnica, sem a qual não seria possível (ADORNO e HORKHEIMER, 2006).

O avanço das técnicas não necessariamente condiz com uma verdadeira emancipação do espectador. A internet, meio no qual as fake news se proliferaram, é mais democrática do que a TV ou o rádio, no sentido em que uma quantidade maior de indivíduos da massa podem ter maior participação em debates de opinião. Mas a situação, na qual pessoas são levadas a aceitar a versão dos fatos que mais the agrada, revela que os consumidores ou espectadores não são emancipados afinal de contas. A massa permanece sujeita aos emissores dos meios de comunicação, mesmo que estes já não sejam a mídia tradicional e sejam um youtuber ou 
o canal oficial de uma pessoa pública. Mesmo porque, os canais de maior alcance dentro do ambiente das mídias sociais, são donos de grande poder material e, consequentemente, de poder simbólico também.

As mensagens, nas quais se incluem as fake news, são produtos dentre os quais os indivíduos escolhem. E tal escolha, na era da pós-verdade, diz respeito ao que o público já acredita, não havendo uma verdadeiro liberdade, já que esta é escrava de crenças a priori. Tais características expõe que as atuais fake news são apenas mais um produto da Indústria Cultural inseridas na sociedade de massa. A diferença se dá apenas nas especificidades dos meios, e a internet se tornou o veículo mais eficaz para práticas políticas.

\section{Conclusão}

A era da pós-verdade e sua consequência, as fake news, dependem, portanto, do surgimento da sociedade de massas e dos meios de comunicação de massa para sua propagação. Notícias falaciosas ao longo da história, documentadas desde pelo menos a invenção da prensa por Gutenberg, não faziam parte de um movimento de massa.

No século XXI, são as redes sociais, tais como Facebook e Twitter que se tornaram os principais meios para atingir um grande número de pessoas.

O fato de que as grandes empresas, detentoras de meios materiais, usem destes meios para seu próprio lucro foi acusado por Adorno e Horkheimer ao ligarem os meios de comunicação e produtos de entretenimento como submissos as indústrias de petróleo, eletricidade, etc. Hoje, elas atuam fomentando a divulgação de fake news por meios alternativos que não necessariamente tenham respaldo de especialistas.

Há de se voltar, então, para a receptividade não crítica da sociedade de massas a despeito de métodos retóricos utilizados, mas sem perder de vista a relevância de um método retórico alheio aos fatos. Mesmo porque, a compreensão das estratégias de comunicação servem para aguçar o olhar e, ao menos, tentar, filtrar os produtos da era da pós-verdade. O "homem- 
massa" de Ortega y Gasset se fez presente no espaço político. Mas não apenas o emissor se encaixa nessa categoria, o receptor também.

Bruce McComiskey identificou um novo tipo de retórica a partir do estudo clássico de Aristóteles. Na era da pós-verdade, não existe uma preocupação com um sentido lógico, de acordo com o autor americano. Não há uma relação com acontecimentos factuais e logo, não se trataria de uma simples mentira. Mas, ao mesmo tempo, o próprio Aristóteles já alertava para a impossibilidade de objetividade nos assuntos humanos, como por exemplo, no contexto de políticas públicas.

A retórica da pós-verdade explora a subjetividade das pessoas, e não tenta impor novas opiniões. A exploração foi apontada pelos frankfurtianos, ao perceberem a subordinação dos meios de comunicação a demais setores da indústria capitalista. A mensagem não é unívoca a partir de critérios objetivos impostos pelos meios de comunicação, antes, esses procuram notícias que já se encaixem na crença de determinado grupo.

Com o advento das mídias sociais houve uma descentralização, mas ainda existem grupos com mais voz do que outros, mesmo que sejam o canal próprio de determinado político ou partido. Afinal, não é qualquer indivíduo que tem grande repercussão na internet. Canais de grande alcance em mídias sociais detém também poder econômico e, portanto, material, suficiente para se fazerem ouvir.

Ademais, os autores que se voltaram para os fenômenos da fake news e da pós-verdade recentemente, como McComiskey, chamaram atenção para o risco que a democracia corre, apesar de nenhum deles entrar em especificidades do regime democrático (McCOMISKEY, 2017). A definição da pós-verdade revela um perigo à democracia, visto que, o indivíduo busca apenas fontes que corroboram suas crenças, e ignoram as demais.

Por outro lado, o problema da difusão de informação (verdadeira ou falsa), por meio de mídias sociais, é algo que só pode ocorrer em democracia. É no regime democrático que um número alto de pessoas tem a liberdade de se comunicarem incessantemente. Por mais, que as principais vozes serão de grandes meios, a divulgação a partir da fonte inicial (no Whatsapp por exemplo), se dá entre iguais. 
Se um grande número de pessoas não tivesse voz, ou não pudesse emitir sua própria opinião,

é possível que a questão aqui analisada não surgisse tal qual aconteceu. Nesse sentido, a teoria da "hiperdemocracia", estipulada por Ortega y Gasset, é corroborada. A democracia da sociedade de massa, como outras formas de governo, não é perfeita e parece ter esbarrado em um de seus limites.

\section{Referências bibliográficas}

ADORNO, Theodor. Indústria cultural e sociedade. São Paulo: Paz e Terra, 2009.

ADORNO, Theodor e HORKHEIMER, Max. Dialética do esclarecimento. Rio de Janeiro:

Zahar, 2006.

ARISTÓTELES. Retórica. São Paulo: Edipro, 2011.

CASSIN, Barbara. O efeito sofístico: sofística, filosofia, retórica, literatura. São Paulo: Editora 34, 2005.

CORBETT, Edward P.J. Classical Rhetoric for the Modern Student. New York: Oxford University Press, 1966.

DUARTE, Rodrigo. Teoria crítica da indústria cultural. Belo Horizonte: Editora UFMG, 2007.

SEXTO EMPIRICUS. Against the Logicians. New York: Cambridge University Press, 2005. MCCOMISKEY, Bruce. Post-Truth Rhetoric and Composition. Colorado: University Press of Colorado, 2017.

ORTEGA Y GASSET, José. La Rebelión de las Masas. Ciudad de México: La Guillotina, 2010.

PLATÃO. Complete Works. Indiana: Hackett Publishing Company, 1997. 